\title{
Evaluation of Inductively Coupled Plasma Tandem Mass Spectrometry for Determination of As in Agricultural Inputs with High REE Contents
}

\author{
Raquel C. Machado, ${ }^{*, a, b}$ Alex Virgilio, ${ }^{a}$ Clarice D. B. Amaral, ${ }^{a, b}$ Daniela Schiavo, ${ }^{c}$ \\ Joaquim A. Nóbrega and Ana Rita A. Nogueira ${ }^{b}$ \\ ${ }^{a}$ Grupo de Análise Instrumental Aplicada, Departamento de Química, Universidade Federal de São \\ Carlos, 13565-905 São Carlos-SP, Brazil \\ ${ }^{b}$ Embrapa Pecuária Sudeste, 13560-970 São Carlos-SP, Brazil \\ ${ }^{c}$ Agilent Technologies, 06455-000 Barueri-SP, Brazil
}

\begin{abstract}
In the present work, an inductively coupled plasma-tandem mass spectrometer (ICP-MS/MS) operating in single quadrupole and mass shift modes were evaluated for As determination in mineral fertilizers and agricultural gypsum with high contents of rare earth elements. For MS/MS mode, oxygen was the gas introduced into the octopole reaction system $\left(\mathrm{ORS}^{3}\right)$. Samples were prepared by microwave-assisted digestion with diluted nitric acid solution. The accuracy was checked by analysis of a fertilizer certified reference material (NIST SRM 695) and by addition and recovery experiments. When operating in single quadrupole mode, recoveries ranged from 59 to $151 \%$; while values obtained by MS/MS mode varied from 81 to $105 \%$ when $0.30 \mathrm{~mL} \mathrm{~min}^{-1}$ $\mathrm{O}_{2}$ was introduced into the $\mathrm{ORS}^{3}$. Limits of detection for $\mathrm{As}^{+}$in single quadrupole and $\mathrm{AsO}^{+}$in MS/MS mass shift mode were 6 and $9 \mathrm{ng} \mathrm{L}^{-1}$, respectively.
\end{abstract}

Keywords: arsenic, double charged interference, fertilizer, gypsum, ICP-MS/MS

\section{Introduction}

The growth of food production over the years contributed to increasing the application of agricultural inputs to soils. In addition to nutrients, agricultural inputs may also be a source of toxic elements as $\mathrm{As}, \mathrm{Cd}, \mathrm{Cr}, \mathrm{Hg}$ and $\mathrm{Pb}$ at trace levels, which can accumulate in the soil and enter into the food chain, therefore their concentrations need to be monitored. ${ }^{1}$ The toxic effects of inorganic arsenic exposure on human health are well reported in the literature and some of the negative secondary effects on lung, liver, skin and bladder cancers, diabetes, cardiovascular and neurological diseases are among them. ${ }^{2}$

The minerals fertilizers (i.e., phosphate fertilizers) and soil conditioners as agricultural gypsum, a coproduct of phosphate fertilizers processing plants, are inputs that contain macronutrients $(\mathrm{Ca}, \mathrm{Mg}, \mathrm{N}, \mathrm{P}$, and $\mathrm{S}$ ), micronutrients (such as $\mathrm{Fe}$ and $\mathrm{Si}$ ), rare earth elements (REEs, such as Ce, Dy, Er, Eu, Gd, Ho, La, Lu, Nd, Pr, $\mathrm{Sc}, \mathrm{Sm}, \mathrm{Tb}, \mathrm{Tm} \mathrm{Y}$, and $\mathrm{Yb}$ ) and, in some cases, toxic elements ( $\mathrm{As}, \mathrm{Cd}, \mathrm{Hg}$ and $\mathrm{Pb}$ ) in their composition.

*e-mail: raquelcm.quim@gmail.com
Spectral interferences can impair the determination of As in this type of samples. ${ }^{3-5}$

Inductively coupled plasma mass spectrometry (ICP-MS) has been employed for trace elements determination, such as As, due to its high sensitivity, multielemental capability indicating the possibility of carrying out the determination of several elements in the same run, wide linear range and lower limits of detection. ${ }^{6,7}$ Accurate ${ }^{75} \mathrm{As}^{+}$determination is usually a challenge because of the well-known isobaric overlaps caused by polyatomic species, such as ${ }^{40} \mathrm{Ar}^{35} \mathrm{Cl}^{+}$, originated from the presence of elements of the matrix in the argon plasma. ${ }^{8-10}$

In addition to polyatomic interferences, double charged species may also affect the accurate determination of As. Some of these species, such as ${ }^{150} \mathrm{Nd}^{2+}$ and ${ }^{150} \mathrm{Sm}^{2+}$, are easily produced in plasma when the sample contains REEs which can overlap the As ${ }^{+}$isotope at $m / z 75 .{ }^{8,9}$ Correction equations, ${ }^{11}$ collision and reaction interface (CRI), ${ }^{12}$ and dynamic reaction cell (DRC) ${ }^{13}$ are useful strategies to overcome these interferences. The recently proposed ICP-MS/MS, designed with two quadrupoles in-between an octopole-based collision/reaction cell $\left(\mathrm{ORS}^{3}\right)$, presents an attractive configuration that provides more efficient 
reaction/collision processes and better conditions to deal with spectral overlaps. ${ }^{14-19}$

Amaral et al. ${ }^{20}$ verified the effectiveness of ICP-MS/MS with $\mathrm{O}_{2}$ into the $\mathrm{ORS}^{3}$ for the elimination of interferences caused by chloride ions ${ }^{40} \mathrm{Ar}^{35} \mathrm{Cl}^{+},{ }^{35} \mathrm{Cl}^{16} \mathrm{OH}^{+}$and ${ }^{35} \mathrm{Cl}^{16} \mathrm{O}^{+}$on $\mathrm{As}^{+}, \mathrm{Cr}^{+}$and $\mathrm{V}^{+}$determination, respectively. The analytes were determined by their oxides with good accuracy, precision and sensitivity. Flórez et al. ${ }^{21}$ exploited a mixture of $\mathrm{CH}_{3} \mathrm{~F} / \mathrm{He}(1 / 9)$ as reaction gas in single quadrupole ICP-MS to determine As from monitoring at ratio $\mathrm{m} / z 89$ (by reaction product $\mathrm{AsCH}_{2}{ }^{+}$between $\mathrm{As}^{+}$and $\mathrm{CH}_{3} \mathrm{~F}$ ) in biological fluids that have high $\mathrm{Cl}$ concentration. Bolea-Fernandez et al. ${ }^{22}$ determined As and Se interference free by ICP-MS/MS using $\mathrm{CH}_{3} \mathrm{~F}$ (a mixture of $10 \%$ $\mathrm{CH}_{3} \mathrm{~F}$ and $90 \% \mathrm{He}$ ) as reaction gas, via $\mathrm{AsCH}_{2}{ }^{+}$and $\mathrm{SeCH}_{2}{ }^{+}$reaction products in different plant, animal and environmental reference materials.

Jackson et al..${ }^{23}$ used an ICP-MS/MS configuration with collision $(\mathrm{He})$ and reaction $\left(\mathrm{H}_{2}\right)$ gases pressurized into the $\mathrm{ORS}^{3}$ in single quadrupole mode and $\mathrm{O}_{2}$ in MS/MS mass shift mode to determine As and Se in two certified reference materials (CRM) of plant tissues, both with high REEs contents. The authors noticed that the formation of $\mathrm{AsO}^{+}$and $\mathrm{SeO}^{+}$and the rejection of non-target ions in MS/MS mode were required in order to gain accuracy. In another study, Jackson ${ }^{24}$ employed an ion chromatographyICP-MS/MS mass shift mode to determine arsenocholine $(\mathrm{AsC})$, arsenobetaine (AsB), dimethylarsine (DMA), monomethylarsine (MMA), $\mathrm{As}^{\mathrm{III}}$ and $\mathrm{As}^{\mathrm{V}}$ in CRMs of urine samples and the method developed provided better detection limits, high sensitivity and sample throughput when compared to others methods.

Inorganic arsenic was determined by hydride generation (HG-ICP-MS) and high performance liquid chromatography (HPLC-ICP-MS) in rice product samples using single quadrupole and MS/MS mass shift mode, with $\mathrm{O}_{2}$ pressurized into the $\mathrm{ORS}^{3}$. Pétursdóttir et al..$^{25}$ compared the results obtained by both methods and suggested that HPLC-ICP-MS can be replaced by simple HG system which provide As concentrations in the sample extract from low $\mu \mathrm{g} \mathrm{L}^{-1}$ levels.

Many countries regulate the maximum limit for As concentration in agricultural inputs. In Canada, the Federal Fertilizers Act regulates the maximum concentration as $75 \mathrm{mg} \mathrm{kg}^{-1}$. In the United States, this concentration changes in different states, ranging from 13 to $112 \mathrm{mg} \mathrm{kg}^{-1}$ depending on the composition of inputs. In Brazil, the Ministry of Agriculture, Livestock and Food Supply establishes the maximum allowed limits for As in fertilizers as $4,000 \mathrm{mg} \mathrm{kg}^{-1} .^{26-28}$

In the present work, the performance of an ICP-MS/MS operating in both single quadrupole and MS/MS mass shift mode, using oxygen as a reaction gas, was evaluated to overcome REEs based interferences on As determination in mineral fertilizers and agricultural gypsum samples.

\section{Experimental}

Reagents, solutions and samples

All materials employed were decontaminated by immersion in $10 \%(\mathrm{v} / \mathrm{v}) \mathrm{HNO}_{3}$ for at least $24 \mathrm{~h}$ and rinsed with distilled-deionized water (resistivity $>18.2 \mathrm{M} \Omega \mathrm{cm}$ ), obtained from a Milli-Q ${ }^{\circledR}$ Water System (Millipore, Billerica, MA, USA). Standard reference solutions and spiked samples were prepared from a $1000 \mathrm{mg} \mathrm{L}^{-1}$ of As (Qhemis, São Paulo, SP, Brazil) stock solution. For sample digestion, $\mathrm{HNO}_{3}$ obtained from a sub-boiling distillation system (Milestone, Sorisole, Italy) and $\mathrm{H}_{2} \mathrm{O}_{2} 30 \%(\mathrm{~m} / \mathrm{m})$ (Qhemis) were used.

Samples of mineral fertilizers and agricultural gypsum from different regions were supplied by the National Laboratory for Agriculture (Goiânia, GO, Brazil) and Embrapa Southeast Livestock (São Carlos, SP, Brazil). A fertilizer certified reference material, SRM 695, from the National Institute of Standards and Technology (NIST, Gaithersburg, MD, USA) was used to check the accuracy.

Instrumentation

All measurements were carried out in an Agilent 8800 inductively coupled plasma tandem mass spectrometer ICP-MS/MS (Agilent Technologies, Tokyo, Japan) equipped with $\mathrm{ORS}^{3}$ located between two quadrupole mass analyzers. Liquid argon was provided by White Martins (Sertãozinho, SP, Brazil). Pure oxygen ( $\geq 99.999 \%$, Air Products, São Paulo, SP, Brazil) was used as cell gas. The single quadrupole and MS/MS mass shift modes were evaluated. The operational parameters are presented in Table 1. Samples were digested using an Ethos 1 microwave oven (Milestone) and were analyzed in triplicate.

\section{Sample preparation}

Mineral fertilizers and agricultural gypsum sample masses (ca. $200 \mathrm{mg}$ ) were accurately weighed and aliquots of $6 \mathrm{~mL}$ of $\mathrm{HNO}_{3} 7 \mathrm{~mol} \mathrm{~L}^{-1}$ and $2 \mathrm{~mL}$ of $\mathrm{H}_{2} \mathrm{O}_{2} 30 \%(\mathrm{~m} / \mathrm{m})$ were added to the vessels. The microwave oven two-step heating program was applied as follows: (i) $20 \mathrm{~min}$ ramp to $200{ }^{\circ} \mathrm{C}$; (ii) $20 \mathrm{~min}$ plateau at $200{ }^{\circ} \mathrm{C}$. After cooling down, the digested samples were transferred to polypropylene flasks and volumes were made up to $50.0 \mathrm{~mL}$ with distilleddeionized water. All samples were digested in triplicate. 
Table 1. Operating conditions for the Agilent 8800 ICP-MS/MS

\begin{tabular}{|c|c|c|c|}
\hline Parameter & \multicolumn{3}{|c|}{ Operating condition } \\
\hline RF applied power / W & \multicolumn{3}{|c|}{1550} \\
\hline Plasma gas flow rate / $\left(\mathrm{L} \mathrm{min}^{-1}\right)$ & \multicolumn{3}{|c|}{18} \\
\hline Auxiliary gas flow rate / $\left(\mathrm{L} \mathrm{min}^{-1}\right)$ & \multicolumn{3}{|c|}{1.8} \\
\hline Carrier gas flow rate / $\left(\mathrm{L} \mathrm{min}^{-1}\right)$ & \multicolumn{3}{|c|}{1.08} \\
\hline Nebulizer & \multicolumn{3}{|c|}{ concentric nebulizer } \\
\hline Spray chamber & \multicolumn{3}{|c|}{ Scott type-double pass } \\
\hline Sampling depth / mm & \multicolumn{3}{|c|}{8} \\
\hline Number of replicates & \multicolumn{3}{|c|}{3} \\
\hline Mass/charged ratio selected- $\mathrm{Q}_{1}$ & \multicolumn{3}{|c|}{$75\left(\mathrm{As}^{+}\right), 150\left(\mathrm{Nd}^{+}, \mathrm{Sm}^{+}\right)$} \\
\hline Mass/charged ratio selected- $\mathrm{Q}_{2}$ & \multicolumn{3}{|c|}{$91\left(\mathrm{AsO}^{+}\right), 166\left(\mathrm{NdO}^{+}, \mathrm{SmO}^{+}\right)$} \\
\hline Operating mode & $\begin{array}{c}\text { single } \\
\text { quadrupole }\end{array}$ & \multicolumn{2}{|c|}{ MS/MS } \\
\hline Cell gas & No gas & \multicolumn{2}{|c|}{$\mathrm{O}_{2}$} \\
\hline $\mathrm{O}_{2}$ flow rate $/\left(\mathrm{mL} \mathrm{min}^{-1}\right)$ & 0 & 0.30 & 0.50 \\
\hline
\end{tabular}

MS/MS: tandem mass spectrometry.

\section{Results and Discussion}

Double charged ion monitoring and determination of elements at $m / z 150$ in agricultural inputs

The $\mathrm{As}^{+}$isotope at $\mathrm{m} / \mathrm{z} 75$ is overlapped by double charged species formed by ${ }^{150} \mathrm{Sm}^{2+}$ or ${ }^{150} \mathrm{Nd}^{2+}$ present in mineral fertilizer, agricultural gypsum and SRM 695 samples, which can cause an overestimation of the ${ }^{75} \mathrm{As}^{+}$ concentrations. To check the presence of interfering species, the net signal intensities at $\mathrm{m} / \mathrm{z} 150$ were monitored in the blank solution $1 \%(\mathrm{v} / \mathrm{v}) \mathrm{HNO}_{3}$ and in the samples using single quadrupole mode (Figure 1). As it can be seen, the signal intensities of agricultural gypsum samples are 7 to 400-fold higher than those observed for mineral fertilizers and SRM 695, respectively.

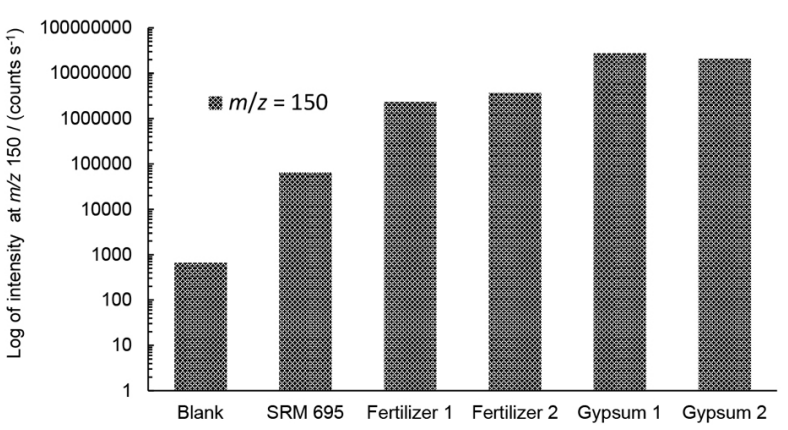

Figure 1. Net signal intensities at $\mathrm{m} / \mathrm{z}, 150$ for blank solution $1 \%(\mathrm{v} / \mathrm{v})$ $\mathrm{HNO}_{3}$, SRM (695), fertilizer and gypsum samples obtained in single quadrupole mode.

In order to check if the high intensities observed at $m / z, 150$ were originated from REE ions or oxide ions as ${ }^{132} \mathrm{Ba}^{18} \mathrm{O}^{+}$and ${ }^{134} \mathrm{Ba}^{16} \mathrm{O}^{+}$, since $\mathrm{Ba}$ is present at high concentrations, the concentrations of ${ }^{150} \mathrm{Nd}^{+}$and ${ }^{150} \mathrm{Sm}^{+}$in the samples were determined in the single quadrupole and MS/MS mass shift modes as ${ }^{150} \mathrm{Nd}^{16} \mathrm{O}^{+}$and ${ }^{150} \mathrm{Sm}^{16} \mathrm{O}^{+}$by introducing $0.30 \mathrm{~mL} \mathrm{~min}^{-1} \mathrm{O}_{2}$ into the $\mathrm{ORS}^{3}$. Results are shown in Table 2. It can be observed that in all samples, the determined concentrations for elements at $m / z 150\left({ }^{150} \mathrm{Nd}^{+}\right.$ or ${ }^{150} \mathrm{Sm}^{+}$) were higher than $100 \mathrm{mg} \mathrm{kg}^{-1}$ and, for agricultural gypsum samples, concentrations 8 to 11 -fold higher than in mineral fertilizers were obtained. No statistical differences were found at a $95 \%$ confidence level ( $t$-test) when both operation modes were considered. Addition and recovery experiments were performed for evaluating the accuracy of the measurements at $m / z 150$ by adding $40 \mu \mathrm{g} \mathrm{L} \mathrm{L}^{-1}$ of $\mathrm{Nd}$ and $\mathrm{Sm}$ to fertilizer and gypsum digests. Recoveries were between 82 to $89 \%$ and 90 to $93 \%$ when operating in single quadrupole and MS/MS mass shift modes, respectively.

Table 2. Determination of ${ }^{150} \mathrm{Nd}^{+}$and ${ }^{150} \mathrm{Sm}^{+}$(mean \pm standard deviation, $\mathrm{n}=3$ ) in mineral fertilizers and agricultural gypsum in single quadrupole and MS/MS mass shift modes $\left(0.30 \mathrm{~mL} \mathrm{~min}^{-1} \mathrm{O}_{2}\right.$ into the $\left.\mathrm{ORS}^{3}\right)$

\begin{tabular}{lcc}
\hline Sample & $\begin{array}{c}\text { Single quadrupole mode } \\
\left({ }^{150} \mathrm{Nd}^{+},{ }^{150} \mathrm{Sm}^{+}\right)\end{array}$ & $\begin{array}{c}\text { MS/MS mass shift mode } \\
\left({ }^{150} \mathrm{Nd}^{16} \mathrm{O}^{+},{ }^{150} \mathrm{Sm}^{16} \mathrm{O}^{+}\right)\end{array}$ \\
\cline { 2 - 3 } & $\begin{array}{c}\text { Determined } \\
\text { concentration / } \\
\left(\mathrm{mg} \mathrm{kg}^{-1}\right)\end{array}$ & $\begin{array}{c}\text { Determined } \\
\text { concentration / } \\
\left(\mathrm{mg} \mathrm{kg}^{-1}\right)\end{array}$ \\
\hline Fertilizer 1 & $213 \pm 4$ & $231 \pm 4$ \\
Fertilizer 2 & $126 \pm 8$ & $126 \pm 5$ \\
Gypsum 1 & $1459 \pm 57$ & $1433 \pm 47$ \\
Gypsum 2 & $1037 \pm 35$ & $1004 \pm 37$ \\
\hline
\end{tabular}

MS/MS: tandem mass spectrometry.

Effect of double charged ions ${ }^{150} \mathrm{Sm}^{2+}$ and ${ }^{150} \mathrm{Nd}^{2+}$ on ${ }^{75} \mathrm{As}^{+}$ analytical signal intensities

The effects of ${ }^{150} \mathrm{Sm}^{2+}$ and ${ }^{150} \mathrm{Nd}^{2+}$ on ${ }^{75} \mathrm{As}^{+}$net signal intensities were evaluated in solutions containing $1.0 \mu \mathrm{g} \mathrm{L}^{-1}$ As in the presence of 0, 5, 10, 20, 40, 70 and $100 \mu \mathrm{g} \mathrm{L}^{-1} \mathrm{Nd}$ and $\mathrm{Sm}$ (Figure 2). Signal intensities were obtained in single quadrupole $\left({ }^{75} \mathrm{As}^{+}\right)$and MS/MS mass shift modes $\left({ }^{75} \mathrm{As}^{16} \mathrm{O}^{+}\right.$, $0.30 \mathrm{~mL} \mathrm{~min}^{-1}$ into the $\mathrm{ORS}^{3}$ ) and normalized to 1 when $\mathrm{Nd}$ and $\mathrm{Sm}$ were absent. It is important to emphasize that in the case of single quadrupole measurements, ${ }^{75} \mathrm{As}^{+}$was the monitored specie while in MS/MS mass shift mode, oxides were easily formed into the $\mathrm{ORS}^{3}$ when $\mathrm{O}_{2}$ was introduced, thus ${ }^{75} \mathrm{As}^{16} \mathrm{O}^{+}$was selected for measurements at the second quadrupole.

As can be seen in Figure 2, when $\mathrm{Nd}$ and $\mathrm{Sm}$ concentrations increased, the signal at $\mathrm{m} / \mathrm{z} .75$ in single quadrupole also increased up to $60 \%$ due to spectral interferences caused by double charged species. When the 
MS/MS mass shift mode was applied, the observed gain was lower than 7\%, thus evidencing that the addition of oxygen into the ORS ${ }^{3}$ cell, the mass shift from ${ }^{75} \mathrm{As}^{+}$to ${ }^{75} \mathrm{As}^{16} \mathrm{O}^{+}$and the selection of the oxide specie in the second quadrupole $\left(Q_{2}\right)$ are efficient strategies to eliminate double charged ions interferences caused by REEs. It is also important to consider that possible interfering species, such as ${ }^{91} \mathrm{Zr}^{+}$, at the same mass/charge ratio of ${ }^{75} \mathrm{As}^{16} \mathrm{O}^{+}$are rejected in the first quadrupole $\left(Q_{1}\right)$ by allowing only $m / z, 75$ ions to pass through.

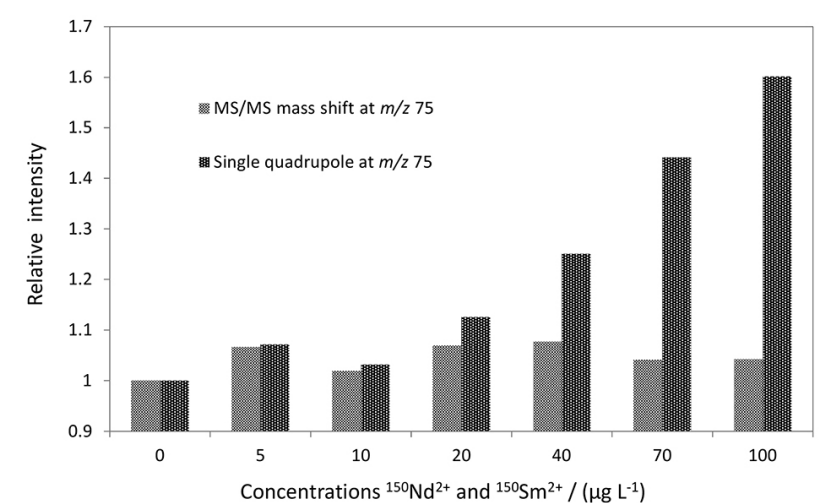

Figure 2. Relative signal intensities on $m / z 75$ for $1 \mu \mathrm{g} \mathrm{L}^{-1}$ As and increasing concentrations of $\mathrm{Sm}$ and $\mathrm{Nd}$ in single quadrupole and MS/MS mass shift modes.

\section{Analytical performance and accuracy}

The analytical performance of ICP-MS/MS for As determination was evaluated for ${ }^{75} \mathrm{As}^{+}$(single quadrupole mode) and ${ }^{75} \mathrm{As}^{16} \mathrm{O}^{+}$(MS/MS mass shift mode). Limits of detection and sensitivities for As in single quadrupole and MS/MS mass shift modes are shown in Table 3. When oxygen gas was introduced into the $\mathrm{ORS}^{3}$, it was observed a sensitivity reduction and higher limit of detection (LOD) values when compared to single quadrupole mode in the absence of cell gas, probably due to the ion beam defocusing and the efficiency of the reaction processes. Despite the lower background signals obtained in MS/MS mode, the effect on sensitivity is even more pronounced when the oxygen flow rate was increased from 0.30 to $0.50 \mathrm{~mL} \mathrm{~min}^{-1}$.

The ICP-MS operated in single quadrupole mode and MS/MS mass shift mode (with different oxygen flow rates into the $\mathrm{ORS}^{3}$ ) was evaluated for correction of interferences at $m / z 75$. The accuracy for As determination in mineral fertilizer samples was evaluated using NIST SRM 695 (Table 4). Using the unpaired $t$-test, no significant differences between the determined and certified values at a 95\% confidence level were observed and the recoveries found varied from 93 to $95 \%$ in all cases. It can be inferred that no significant improvement in accuracy was achieved using MS/MS mass shift mode with $\mathrm{O}_{2}$ into the $\mathrm{ORS}^{3}$, which can be explained considering the low net signal intensity for $\mathrm{m} / \mathrm{z} 150$ (Figure 1) in this particular material.

In order to evaluate the accuracy in samples containing higher contents of elements that produce interfering double charged species, addition and recovery experiments for As at two levels (Table 4) were performed for agricultural gypsum and fertilizer samples. Recoveries obtained in single quadrupole mode ranged from 59 to $151 \%$, while values obtained by MS/MS mass shift mode varied from 81 to $105 \%$ and 81 to $107 \%$ for $\mathrm{O}_{2}$ flow rates of 0.30 and $0.50 \mathrm{~mL} \mathrm{~min}^{-1}$, respectively. Recoveries observed in single quadrupole mode presented deviations higher than $20 \%$, which are related to overlaps caused by double charged ions on ${ }^{75} \mathrm{As}^{+}$.

The As concentrations in minerals fertilizers and agricultural gypsum were determined in different instrumental conditions (Table 5). In single quadrupole mode determined concentrations are higher than those determined by MS/MS mass shift mode and this difference is more pronounced in agricultural gypsum samples, which present concentrations of elements at $\mathrm{m} / z .150\left({ }^{150} \mathrm{Nd}^{+}\right.$ and ${ }^{150} \mathrm{Sm}^{+}$) up to 10 -fold higher than those found in fertilizers. A paired $t$-test was used to check the agreement of results obtained by two oxygen gas flow rates $(0.30$ and $0.50 \mathrm{~mL} \mathrm{~min}^{-1}$ ) and no statistical differences were found at a $95 \%$ confidence level. It was possible to verify the effectiveness of MS/MS mass shift mode using $\mathrm{O}_{2}$ into the $\mathrm{ORS}^{3}$ to overcome double charged ions interferences on ${ }^{75} \mathrm{As}^{+}$determination.

\section{Conclusions}

The use of MS/MS mass shift mode was effective to remove double charged interferences from REEs on As determination in mineral fertilizers and agricultural gypsum

Table 3. Limits of detection (LOD) and sensitivities for ${ }^{75} \mathrm{As}^{+}$in single quadrupole and MS/MS modes with different oxygen gas flow rates

\begin{tabular}{|c|c|c|c|c|c|}
\hline \multicolumn{2}{|c|}{$\begin{array}{l}\text { Single quadrupole mode } \\
\qquad\left({ }^{75} \mathrm{As}^{+}\right)\end{array}$} & \multicolumn{2}{|c|}{$\begin{array}{c}0.30 \mathrm{~mL} \mathrm{~min}^{-1} \mathrm{O}_{2} \\
\left({ }^{75} \mathrm{As}^{16} \mathrm{O}^{+}\right)\end{array}$} & \multicolumn{2}{|c|}{$\begin{array}{c}0.50 \mathrm{~mL} \mathrm{~min}^{-1} \mathrm{O}_{2} \\
\left({ }^{75} \mathrm{As}^{16} \mathrm{O}^{+}\right)\end{array}$} \\
\hline $\mathrm{LOD} /\left(\mathrm{ng} \mathrm{L}^{-1}\right)$ & Sensitivity $^{\mathrm{a}}$ & $\mathrm{LOD} /\left(\mathrm{ng} \mathrm{L}^{-1}\right)$ & Sensitivity $^{\mathrm{a}}$ & $\mathrm{LOD} /\left(\mathrm{ng} \mathrm{L}^{-1}\right)$ & Sensitivity $^{\mathrm{a}}$ \\
\hline 6.0 & 22869 & 9.0 & 9452 & 40.0 & 6273 \\
\hline
\end{tabular}

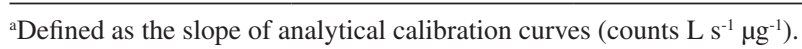


Table 4. Determination of As (mean \pm standard deviation, $n=3$ ) in fertilizer (SRM 695) and in spiked samples of agricultural gypsum and mineral fertilizer in single quadrupole mode and MS/MS mass shift mode with different oxygen gas flow rates

\begin{tabular}{|c|c|c|c|c|c|c|c|}
\hline \multirow[t]{2}{*}{ Sample } & \multicolumn{3}{|c|}{$\begin{array}{l}\text { Single quad mode } \\
\qquad\left({ }^{75} \mathrm{As}^{+}\right)\end{array}$} & \multicolumn{2}{|c|}{$\begin{array}{c}\text { MS/MS } 0.30 \mathrm{~mL} \mathrm{~min}^{-1} \\
\mathrm{O}_{2}\left({ }^{75} \mathrm{As}^{16} \mathrm{O}^{+}\right) \\
\end{array}$} & \multicolumn{2}{|c|}{$\begin{array}{l}\text { MS/MS } 0.50 \mathrm{~mL} \mathrm{~min}^{-1} \\
\mathrm{O}_{2}\left({ }^{75} \mathrm{As}^{16} \mathrm{O}^{+}\right)\end{array}$} \\
\hline & $\begin{array}{c}\text { Certified value / } \\
\quad\left(\mu \mathrm{g} \mathrm{L}^{-1}\right)\end{array}$ & $\begin{array}{l}\text { Determined / } \\
\left(\mathrm{mg} \mathrm{kg}^{-1}\right)\end{array}$ & $\begin{array}{c}\text { Recovery / } \\
\%\end{array}$ & $\begin{array}{l}\text { Determined / } \\
\left(\mathrm{mg} \mathrm{kg}^{-1}\right)\end{array}$ & Recovery / \% & $\begin{array}{l}\text { Determined / } \\
\left(\mathrm{mg} \mathrm{kg}^{-1}\right)\end{array}$ & Recovery / \% \\
\hline \multirow[t]{2}{*}{ SRM 695} & $200.0 \pm 5$ & $187.4 \pm 12.5$ & 94 & $190.7 \pm 17.9$ & 95 & $186.5 \pm 9.79$ & 93 \\
\hline & $\begin{array}{l}\text { Added / } \\
\left(\mu \mathrm{g} \mathrm{L}^{-1}\right)\end{array}$ & $\begin{array}{l}\text { Determined / } \\
\left(\mu \mathrm{g} \mathrm{L}^{-1}\right)\end{array}$ & $\begin{array}{c}\text { Recovery / } \\
\%\end{array}$ & $\begin{array}{l}\text { Determined / } \\
\left(\mu \mathrm{g} \mathrm{L}^{-1}\right)\end{array}$ & $\begin{array}{c}\text { Recovery / } \\
\%\end{array}$ & $\begin{array}{l}\text { Determined / } \\
\left(\mu \mathrm{g} \mathrm{L}^{-1}\right)\end{array}$ & $\begin{array}{c}\text { Recovery / } \\
\%\end{array}$ \\
\hline \multirow[t]{2}{*}{ Fertilizer 1} & 5.0 & $5.8 \pm 0.3$ & 116 & $4.0 \pm 0.2$ & 81 & $4.1 \pm 0.3$ & 81 \\
\hline & 10.0 & $12.8 \pm 2.1$ & 128 & $9.5 \pm 1.3$ & 95 & $9.5 \pm 1.3$ & 95 \\
\hline \multirow[t]{2}{*}{ Gypsum 1} & 0.50 & $0.76 \pm 0.13$ & 151 & $0.53 \pm 0.02$ & 105 & $0.54 \pm 0.02$ & 107 \\
\hline & 1.0 & $0.59 \pm 0.51$ & 59 & $0.88 \pm 0.09$ & 88 & $0.91 \pm 0.10$ & 91 \\
\hline
\end{tabular}

Table 5. Determination in $\mathrm{mg} \mathrm{kg}^{-1}$ of As (mean \pm standard deviation, $\mathrm{n}=3$ ) in mineral fertilizers and agricultural gypsum using single quadrupole and MS/MS mass shift modes with different oxygen gas flow rates

\begin{tabular}{lccc}
\hline Sample & Single quadrupole & MS/MS 0.30 mL min $\mathrm{O}_{2}$ & $\mathrm{MS} / \mathrm{MS} \mathrm{0.50} \mathrm{mL} \mathrm{min}{ }^{-1} \mathrm{O}_{2}$ \\
\hline Fertilizer 1 & $12.8 \pm 1.1$ & $8.8 \pm 0.7$ & $8.9 \pm 0.7$ \\
Fertilizer 2 & $36.8 \pm 2.5$ & $30.2 \pm 1.6$ & $29.2 \pm 1.4$ \\
Gypsum 1 & $7.9 \pm 0.04$ & $0.36 \pm 0.01$ & $0.37 \pm 0.01$ \\
Gypsum 2 & $6.4 \pm 1.4$ & $0.71 \pm 0.03$ & $0.65 \pm 0.04$ \\
\hline
\end{tabular}

MS/MS: tandem mass spectrometry.

by ICP-MS/MS with proper sensitivity and accuracy. The possibility of a well-controlled conversion of ${ }^{75} \mathrm{As}^{+}$ions to ${ }^{75} \mathrm{As}^{16} \mathrm{O}^{+}$ions by addition of oxygen gas into the $\mathrm{ORS}^{3}$ cell is one of the main advantages of this instrument configuration, and allows the accurate determination of As in samples with high contents of REEs, such as ${ }^{150} \mathrm{Nd}^{2+}$ and ${ }^{150} \mathrm{Sm}^{2+}$. It can cause false positive errors on As determination causing erroneous decisions about commercialization and application of agricultural products, which is critical considering environmental effects and legislations established for controlling these products.

\section{Acknowledgments}

The authors are grateful to grants 2013/26672-5, 2014/18393-1 and 2015/14488-0 of São Paulo Research Foundation (FAPESP) provided to R. C. M., A. V., and A. R. A. N., and Coordenação de Aperfeiçoamento de Pessoal de Nível Superior (CAPES, grant 15/2014) for fellowship to C. D. B. A. J. A. N. and A. R. A. N. are also thankful to the Conselho Nacional de Desenvolvimento Científico e Tecnológico (CNPq, research grants 303107/2013-8, 443771/2014-6, and 307639/2014-2) and the Instituto Nacional de Ciências e Tecnologias Analíticas Avançadas (INCTAA) by research grant. We also thank Agilent Technologies for the technical support.

\section{References}

1. Jiao, W.; Chen, W.; Chang, A. C.; Page, A. L.; Environ. Pollut. 2012, 168, 44.

2. Hughes, M. F.; Beck, B. D.; Chen, Y.; Lewis, A. S.; Thomas, D. J.; Toxicol. Sci. 2011, 123, 305.

3. Hartley, T. N.; MacDonald, A. J.; McGrath, S. P.; Zhao, F. J.; Environ. Pollut. 2013, 180, 259.

4. Thyabat, S. A.; Zhang, P.; Hydrometallurgy 2015, 153, 30.

5. Saueia, C. H. R.; le Bourlegat, F. M.; Mazzilli, B. P.; Fávaro, D. I. T.; J. Radioanal. Nucl. Chem. 2013, 297, 189.

6. Amaral, C. D. B.; Nóbrega, J. A.; Nogueira, A. R. A.; Microchem. J. 2014, 117, 122.

7. Peng, H.; Zhang, N.; He, M.; Chein, B.; Hu, B.; Talanta 2015 , $131,266$.

8. Thomas, R. In Practical Guide to ICP-MS: a Tutorial for Beginners, $3^{\text {rd }}$ ed.; CRC Press: Boca Raton, USA, 2013.

9. Pick, D.; Leiterer, M.; Einax, J. W.; Microchem. J. 2010, 95, 315.

10. Guo, W.; Hu, S.; Li, H.; Zhao, J.; Jin, S.; Liu, W.; Zhang, H.; Talanta 2011, 84, 887.

11. Xing, Y.; Xiaojia, L.; Haizhou, W.; Int. J. Mass Spectrom. 2007, $262,25$.

12. Pereira, C. D.; Garcia, E. E.; Silva, F. V.; Nogueira, A. R. A.; Nóbrega, J. A.; J. Anal. At. Spectrom. 2010, 25, 1763. 
13. D’Ilio, S.; Violante, N.; Majorani, C.; Petrucci, F.; Anal. Chim. Acta 2011, 698, 6.

14. Agilent; Agilent 8800 Triple Quadrupole ICP-MS: Understanding Oxygen Reaction Mode in ICP-MS/MS; Agilent Technologies; Publication Number: 5991-1708EN, 2012.

15. Balcaen, L.; Woods, G.; Resano, M.; Vanhaecke, F.; J. Anal. At. Spectrom. 2013, 28, 33.

16. Amais, R. S.; Amaral, C. D. B.; Fialho, L. L.; Schiavo, D.; Nóbrega, J. A.; Anal. Methods 2014, 6, 4516.

17. Amais, R. S.; Virgilio, A.; Schiavo, D.; Nóbrega, J. A.; Microchem. J. 2015, 120, 64.

18. Balcaen, L.; Bolea-Fernandez, E.; Resano, M.; Vanhaecke, F.; Anal. Chim. Acta 2015, 894, 7.

19. Boting, K.; Treu, S.; Leonhard, P.; Heib, C.; Bings, N. H.; J. Anal. At. Spectrom. 2014, 29, 578.

20. Amaral, C. D. B.; Amais, R. S.; Fialho, L. L.; Schiavo, D.; Amorim, T.; Nogueira, A. R. A.; Nóbrega, J. A.; Anal. Methods 2015, 7, 1215.

21. Flórez, M. R.; García-Ruiz, E.; Bolea-Fernández, E.; Vanhaecke, F.; Resano, M.; J. Anal. At. Spectrom. 2016, 31, 245.

22. Bolea-Fernandez, E.; Balcaen, L.; Resano, M.; Vanhaecke, F.; Anal. Bioanal. Chem. 2015, 407, 919.

23. Jackson, B. P.; Liba, A.; Nelson, J.; J. Anal. At. Spectrom. 2015, 5,1179 .

24. Jackson, B. P.; J. Anal. At. Spectrom. 2015, 30, 1405.
25. Pétursdóttir, A. H.; Friedrich, N.; Musil, S.; Raab, A.; Gunnlaugsdottir, H.; Krupp, E. M.; Feldmann, J.; Anal. Methods 2014, 6, 5392.

26. Canadian Food Inspection Agency (CFIA); Standards for Metals in Fertilizers and Supplements. Available at: http://www. inspection.gc.ca/plants/fertilizers/trade-memoranda/t-4-093/en g/1305611387327/1305611547479, accessed in March 2016.

27. Association of American Plant Food Control Officials (AAPFCO); Statement of Uniform Interpretation and Policy: the Heavy Metal Rule. Available at: http://www.aapfco.org/ rules.html, accessed in March 2016.

28. Ministério da Agricultura Pecuária e Abastecimento (MAPA); Instrução Normativa No. 27, 05 de Junho de 2006, Dispõe Sobre Fertilizantes, Corretivos, Inoculantes e Biofertilizantes, para Serem Produzidos, Importados ou Comercializados, Deverão Atender aos Limites Estabelecidos nos Anexos I, II, III, IV e V desta Instrução Normativa no que se Refere às Concentrações Máximas Admitidas para Agentes Fitotóxicos, Patogênicos ao Homem, Animais e Plantas, Metais Pesados Tóxicos, Pragas e Ervas Daninhas, Publicado no Diário Oficial da União de 09 de Junho de 2006, pp. 15.

Submitted: February 10, 2016 Published online: March 31, 2016

FAPESP has sponsored the publication of this article. 